\title{
Hydrogen Peroxide Treatment and the Phenylpropanoid Pathway Precursors Feeding Improve Phenolics and Antioxidant Capacity of Quinoa Sprouts via an Induction of $L$-Tyrosine and L-Phenylalanine Ammonia-Lyases Activities
}

\begin{abstract}
Michal Świeca
Department of Biochemistry and Food Chemistry, University of Life Sciences, Skromna Street 8, 20-704 Lublin, Poland

Correspondence should be addressed to Michał Świeca; michal.swieca@up.lublin.pl

Received 29 September 2015; Revised 15 February 2016; Accepted 23 February 2016

Academic Editor: Isabel Lara

Copyright (C) 2016 Michał Świeca. This is an open access article distributed under the Creative Commons Attribution License, which permits unrestricted use, distribution, and reproduction in any medium, provided the original work is properly cited.

Hydrogen peroxide treatment and the phenylpropanoid pathway precursors feeding affected the antioxidant capacity of quinoa sprouts. Compared to the control, total phenolics content was significantly increased by treatment of control sprouts with $50 \mathrm{mM}$ and $200 \mathrm{mM} \mathrm{H}_{2} \mathrm{O}_{2}$-an elevation of about $24 \%$ and $28 \%$, respectively. The highest increase of flavonoids content was found for the sprouts treated with $200 \mathrm{mM} \mathrm{H}_{2} \mathrm{O}_{2}$ obtained from seeds fed with shikimic acid. All the studied modifications increased the antioxidant potential of sprouts (at least by $50 \%$ compared to control). The highest reducing power was found for the sprouts treated with $200 \mathrm{mM} \mathrm{H}_{2} \mathrm{O}_{2}$ obtained by phenylalanine feeding $(5.03 \mathrm{mg} \mathrm{TE} / \mathrm{g} \mathrm{DW})$ and those obtained from the seeds fed with tyrosine $(5.26 \mathrm{mg}$ TE/g DW). The activities of L-tyrosine (TAL) and L-phenylalanine (PAL) ammonia-lyases were strongly affected by germination time as well as the applied modification of sprouting. On the 3rd day the highest PAL activity was determined for both untreated and induced with $50 \mathrm{mM} \mathrm{H}_{2} \mathrm{O}_{2}$ sprouts obtained by phenylalanine feeding. $\mathrm{H}_{2} \mathrm{O}_{2}$ induced TAL activity; the highest TAL activity was determined for 3-day-old sprouts induced with $200 \mathrm{mM} \mathrm{H}_{2} \mathrm{O}_{2}$ obtained from seeds fed with phenylalanine.
\end{abstract}

\section{Introduction}

In the last few years, an increasing interest can be observed for food that aside from a high nutritional value provides some additional prohealth effects. These functional products may improve general conditions of the body (e.g., probiotics), may decrease a risk of some diseases (e.g., inflammation, cancer), and could also be useful in the treatment of some illnesses and disorders (e.g., diabetes) [1].

Quinoa seeds are rich in proteins and free essential amino acids, oils, and starch, including resistant starch [2,3]. In addition, it contains a wide range of vitamins (ascorbic acid and tocopherols) and microelements (i.e., phosphorus, copper, manganese, iron, zinc, calcium, magnesium, sodium, and potassium) [2]. For centuries, quinoa has also been cultivated as a leafy vegetable. Leaves contain significant amounts of protein (2.7-3.0\%) and fiber (1.9\%) and are a good source of highly bioaccessible and bioavailable compounds with antioxidant, anti-inflammatory, and anticancer properties $[3,4]$. Prohealth activity of quinoa is associated with high contents of vitamin $\mathrm{E}$ and phenolic compounds $[5,6]$. The level of phenolics in quinoa seeds is strongly determined by cultivar (colour-coating seeds are much better source of phenolics) and cultivation conditions, for example, weather and chemical spraying. Seeds contain phenolic acids (caffeic, ferulic, $p$-coumaric, $p$-OH-benzoic, and vanillic) and flavonoids (mainly kaempferol and quercetin derivatives) [7, 8].

Sprouting causes many biochemical changes in the developing seedlings. Storage materials (protein and starch) are mobilized; micro- and macrominerals become more bioavailable (reduction of phytic acid via an increased activity 
of phytase) [9]. Compared to dormant seeds, sprouts are characterized by a higher bioavailability and bioaccessibility of nutrients, minerals, and vitamins [10]. Unfortunately, in some cases germination caused a significant reduction of phenolics compounds-phytochemicals with well-documented biological activity $[10,11]$. Phenolics are usually lost during soaking of seeds [9] but they may also be used by growing plants as precursors of cell wall components, hormones, and other regulatory compounds [12].

Phenolics are primarily produced through the pentose phosphate, the shikimate, and the phenylpropanoid pathways [12]. Phenylalanine and tyrosine ammonia-lyases, playing a key role in the phenylpropanoid metabolism, convert aromatic amino acids into trans-cinnamic and p-coumaric acids, respectively. The activities of these enzymes are usually induced under stress conditions, which results in an accumulation of "pathogen-related compounds," including phenolics. This phenomenon may be used for improving phenolics overproduction in plant systems [12]. So far, an induction of phenylpropanoids metabolism by elicitors (compounds or conditions inducing stress and further plant response) was successfully used for the production of lentil [13], wheat [14], buckwheat [15], or broccoli sprouts [16]. Additionally, an effectiveness of such treatments may be enhanced by precursors feeding, for example, L-galactose for ascorbic acid [17], tryptophan for sulphoraphane [18] and shikimic acid, and phenylalanine for phenolics synthesis $[15,19]$.

In this study, the effects of hydrogen peroxide treatment and the phenylpropanoid pathway precursors feeding on changes in the phenolics and antioxidant capacity of quinoa sprouts were studied. Special attention was paid to activities of two main enzymes involved in phenolics synthesis which may broaden the knowledge about the mechanisms of their accumulation.

\section{Material and Methods}

2.1. Chemicals. Ferrozine (3-(2-pyridyl)-5,6-bis-(4-phenylsulphonic acid)-1,2,4-triazine), ABTS (2,2' -azino-bis(3-ethylbenzothiazoline-6-sulphonic acid)), ammonium thiocyanate, and polyvinylpyrrolidone were purchased from SigmaAldrich Company (Poznan, Poland). All other chemicals were of analytical grade.

2.2. Materials. Quinoa (Chenopodium quinoa Willd.) "Faro" seeds were cropped in Peru in 2011 and imported by Bio Planet S.A. (product specification QNR/20417). Seeds were sterilized in $1 \%(\mathrm{v} / \mathrm{v})$ sodium hypochloride for $3 \mathrm{~min}$, then drained, and washed with distilled water until they reached neutral $\mathrm{pH}$. After that seeds were placed in distilled water (C: control, $\mathrm{C} 1$, and $\mathrm{C} 2$ ) or solution of phenolic precursor (0.1 mM shikimic acid, S, S1, and S2; $0.1 \mathrm{mM} \mathrm{L-phenylalanine,}$ F, F1, and F2; 0.1 mM L-tyrosine, Y, Y1, and Y2) and soaked for $4 \mathrm{~h}$ at $25^{\circ} \mathrm{C}$. Seeds were dark germinated for 3 days in a growth chamber on Petri dishes $(\phi 125 \mathrm{~mm})$ lined with absorbent paper (approximately 1000 seeds per dish). Seedlings were watered daily with $5 \mathrm{~mL}$ of Milli-Q water. For treatment 1day-old sprouts were sprayed with $5 \mathrm{~mL}$ of $50 \mathrm{mM}(\mathrm{Cl}, \mathrm{F} 1$, and Y1) and $200 \mathrm{mM}$ (C2, F2, and Y2) hydrogen peroxide. The plates were then covered and sprouts were germinated under control conditions. After 3 days, sprouts were gently collected, rapidly frozen, and lyophilised. Seeds and dried sprouts were grounded in a labour mill, sieved (60 mesh), and kept in polyethylene bags at $20^{\circ} \mathrm{C}$ [19].

2.3. Extraction Procedure. Quinoa flour ( $0.25 \mathrm{~g}$ in triplicate) was extracted three times with $4 \mathrm{~mL}$ of ethanol: water $(80: 20$, $\mathrm{v} / \mathrm{v})$. After centrifugation $(10 \mathrm{~min}, 6800 \times \mathrm{g})$ fractions were collected, combined, and used for further analysis.

\subsection{Phenolics Analysis}

2.4.1. Total Phenolics. The amount of total phenolics was determined using Folin-Ciocalteau reagent [20]. To $0.5 \mathrm{~mL}$ of the extract, $0.5 \mathrm{~mL} \mathrm{H}_{2} \mathrm{O}$ and $2 \mathrm{~mL}$ Folin-Ciocalteau reagent $\left(1: 5 \mathrm{H}_{2} \mathrm{O}\right)$ were added and, after $3 \mathrm{~min}, 10 \mathrm{~mL}$ of $10 \%$ $\mathrm{Na}_{2} \mathrm{CO}_{3}$. The contents were mixed and allowed to stand for $30 \mathrm{~min}$. Absorbance at $725 \mathrm{~nm}$ was measured in a UV-Vis spectrophotometer. For the method the calibration curve was prepared using gallic acid solutions at concentrations 1 to $100 \mu \mathrm{g} / \mathrm{mL}$. The amount of total phenolics was expressed as a gallic acid equivalent (GAE) in $\mathrm{mg} / \mathrm{g}$ of dry weight (DW).

2.4.2. Total Flavonoids. Total flavonoids content was determined according to the method described by Lamaison and Carnet [21]. One millilitre of extract was mixed with $1 \mathrm{~mL}$ of $2 \% \mathrm{AlCl}_{3} \times 6 \mathrm{H}_{2} \mathrm{O}$ solution and incubated at room temperature for $10 \mathrm{~min}$. Thereafter, absorbance at $430 \mathrm{~nm}$ was measured. For the method, the calibration curve was prepared using a quercetin solution at concentrations 1 to $100 \mu \mathrm{g} / \mathrm{mL}$. Total flavonoids content was calculated as quercetin equivalent $(\mathrm{QE})$ in $\mathrm{mg} / \mathrm{g}$ of dry weight (DW).

\subsection{Antioxidant Activities}

2.5.1. Antiradical Activity (ABTS). The experiments were carried out using the ABTS decolorization assay [22]. The ABTS radical cation $\left(\mathrm{ABTS}^{+\bullet}\right.$ ) was produced by reacting $7 \mathrm{mM}$ stock solution of ABTS with $2.45 \mathrm{mM}$ potassium persulphate (final concentration) and allowing the mixture to stand in the dark for at least $6 \mathrm{~h}$ at room temperature prior to use. The $\mathrm{ABTS}^{+\bullet}$ solution was diluted to an absorbance of $0.7 \pm 0.05$ at $734 \mathrm{~nm}$ (Lambda 40 UV-Vis spectrophotometer, PerkinElmer Inc., Waltham, USA). Then, $40 \mu \mathrm{L}$ of the extract obtained after digestion in vitro was added to $1.8 \mathrm{~mL}$ of $\mathrm{ABTS}^{+\bullet}$ solution and the absorbance was measured at the end time of $5 \mathrm{~min}$. The affinity of test material to quench ABTS free radical was evaluated according to the following equation:

$$
\text { scavenging } \%=\left[\frac{\left(A_{C}-A_{A}\right)}{A_{C}}\right] \times 100 \text {, }
$$

where $A_{C}$ is the absorbance of control and $A_{A}$ is the absorbance of the extract obtained after digestion in vitro.

For the method the calibration curve was prepared using Trolox solutions at concentrations 1 to $100 \mu \mathrm{g} / \mathrm{mL}$. Free 
radical scavenging ability was expressed as Trolox equivalent in $\mathrm{mg} / \mathrm{g} \mathrm{DW}$.

2.5.2. Reducing Power (RP). Reducing power was determined using the method described based on the ability of the extracts to reduce iron (III) [23]. Extracts $(0.5 \mathrm{~mL})$ were mixed with phosphate buffer $(0.5 \mathrm{~mL}, 200 \mathrm{mmol} / \mathrm{L} \mathrm{pH} \mathrm{6.6)}$ and $0.5 \mathrm{~mL}$ of $1 \%$ aqueous solution of potassium ferricyanide $\mathrm{K}_{3}\left[\mathrm{Fe}\left(\mathrm{CN}_{6}\right)\right]$. The mixture was incubated at $50^{\circ} \mathrm{C}$ for $20 \mathrm{~min}$. A portion $(0.1 \mathrm{~mL})$ of $10 \%$ trichloroacetic acid was added to the mixture, which was then centrifuged at $6800 \times \mathrm{g}$ for $10 \mathrm{~min}$. The upper layer of solution $(0.5 \mathrm{~mL})$ was mixed with distilled water $(0.5 \mathrm{~mL})$ and $0.1 \mathrm{~mL}$ of $1 \mathrm{~g} / \mathrm{L} \mathrm{FeCl}_{3}$, and the absorbance was measured at $700 \mathrm{~nm}$. For the method the calibration curve was prepared using Trolox solutions at concentrations 1 to $100 \mu \mathrm{g} / \mathrm{mL}$. The ability of the extracts to reduce iron (III) was calculated as a Trolox equivalent (TE) in $\mathrm{mg} / \mathrm{g} \mathrm{DW}$.

2.5.3. Metal Chelating Activity (CHP). Chelating power was determined by the method of Decker and Welch [24]. The extract $(5 \mathrm{~mL})$ was added to $0.1 \mathrm{~mL}$ of $2 \mathrm{mM} \mathrm{FeCl}_{2}$ solution and $0.2 \mathrm{~mL} 5 \mathrm{mM}$ ferrozine and the mixture was shaken vigorously and left standing at room temperature for $10 \mathrm{~min}$. Then, absorbance of the solution was measured spectrophotometrically at $562 \mathrm{~nm}$. The percentage of inhibition of ferrozine-Fe ${ }^{2+}$ complex formation was calculated according to the following formula:

$$
\% \text { inhibition }=\left[1-\left(\frac{A_{p}}{A_{C}}\right)\right] \times 100,
$$

where $A_{C}$ is the absorbance of control and $A_{p}$ is the absorbance of sample

For the method the calibration curve was prepared using EDTA solutions at concentrations 1 to $100 \mu \mathrm{g} / \mathrm{mL}$. Chelating power was expressed as EDTA equivalent in $\mathrm{mg} / \mathrm{g} \mathrm{DW}$.

2.5.4. Total Antioxidant Capacity. Four complementary antioxidant tests were intergraded for evaluation of total antioxidant capacity (AI) (3). The AI was calculated as the sum of relative activities (RA) (4) for each antioxidant method divided by the number of methods $(n)$ [25]:

$$
\mathrm{AI}=\frac{\sum \mathrm{RA}_{(n)}}{n} .
$$

RA was calculated as follows:

$$
\mathrm{RA}=\frac{A_{x}}{A_{C}}
$$

where $A_{x}$ is the activity of modified sprouts for the method and $A_{C}$ is the activity of control sprouts determined for the method.

\subsection{Enzymatic Activities}

2.6.1. Extract Preparation. All enzyme extraction procedures were conducted at $4^{\circ} \mathrm{C}$. A $200 \mathrm{mg}$ of lyophilized sample (seeds, sprouts) was ground with $2 \mathrm{~mL}$ extracting buffer ( $0.2 \mathrm{M}$ boric acid buffer containing $1 \mathrm{mM}$ EDTA, and $50 \mathrm{mM}$ $\beta$-mercaptoethanol, $\mathrm{pH} 8.8$ ). The extracts were then homogenized and centrifuged at $12000 \times \mathrm{g}$ at $4^{\circ} \mathrm{C}$ for $30 \mathrm{~min}$, and the supernatant was collected [26].

\subsubsection{Enzyme Assay}

(1) Tyrosine Ammonia-Lyase (TAL) Assay. For the TAL assay, $100 \mu \mathrm{L}$ of the extract was incubated with $0.9 \mathrm{~mL} 0.02 \mathrm{M} \mathrm{L}$ tyrosine at $30^{\circ} \mathrm{C}$ for $60 \mathrm{~min}$. After incubations, $0.5 \mathrm{~mL} 10 \%$ trichloroacetic acid (TCA) was added to stop the reaction, samples were centrifuged $(15000 \times \mathrm{g}, 10 \mathrm{~min})$, and absorbance at $310 \mathrm{~nm}$ was measured. For the method the calibration curve was prepared using $p$-coumaric acid solutions at concentrations 1 to $100 \mu \mathrm{g} / \mathrm{mL}$. One unit was defined as the amount of enzyme that produced $1.0 \mu \mathrm{g} p$-coumaric acid per min under the conditions of the assay. The results were presented as $U$ per mg of protein [26].

(2) Phenylalanine Ammonia-Lyase (PAL) Assay. For the PAL assay, $300 \mu \mathrm{L}$ of the extract was incubated with $1.2 \mathrm{~mL} 0.02 \mathrm{M}$ L-phenylalanine and $2 \mathrm{~mL}$ of the PAL extracting buffer at $30^{\circ} \mathrm{C}$ for $60 \mathrm{~min}$. After incubations, $0.5 \mathrm{~mL} 10 \%$ TCA was added to stop the reaction, samples were centrifuged $(15000 \times \mathrm{g}, 10 \mathrm{~min})$, and absorbance at $290 \mathrm{~nm}$ was measured. For the method the calibration curve was prepared using trans-cinnamic acid solutions at concentrations 1 to $100 \mu \mathrm{g} / \mathrm{mL}$. One unit was defined as the amount of enzyme that produced $1.0 \mu \mathrm{g}$ trans-cinnamic acid per min under the conditions of the assay. The results were presented as $U$ per mg of protein [26].

2.7. Protein Assay. The proteins content was determined with the Bradford method, using bovine serum albumin as the standard protein [27].

2.8. Statistical Analysis. All experimental results were mean $\pm \mathrm{SD}$ of three independent experiments $(n=9)$. One-way analysis of variance (ANOVA) and Turkey's post hoc test were used to compare groups (seeds as well as control and treated sprouts) (STATISTICA 6, StatSoft, Inc., Tulsa, USA). Differences were considered significant at $p<0.05$.

\section{Results and Discussion}

Phenolics content and antioxidant capacity of quinoa sprouts are determined by many factors such as genetics, germination conditions, and further storage $[8,28]$.

The effect of the phenylpropanoid pathway precursors feeding and hydrogen peroxide treatments on the sprouts phenolics is presented in Figure 1. Compared to the control, treatments with $50 \mathrm{mM}$ and $200 \mathrm{mM} \mathrm{H}_{2} \mathrm{O}_{2}$ significantly $(p<$ 0.05 ) increased the total phenolics content by about $24 \%$ and 


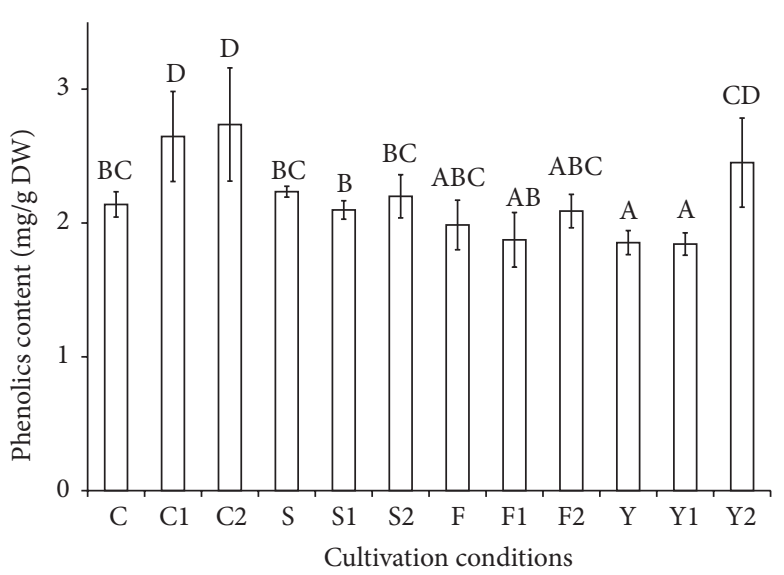

(a)

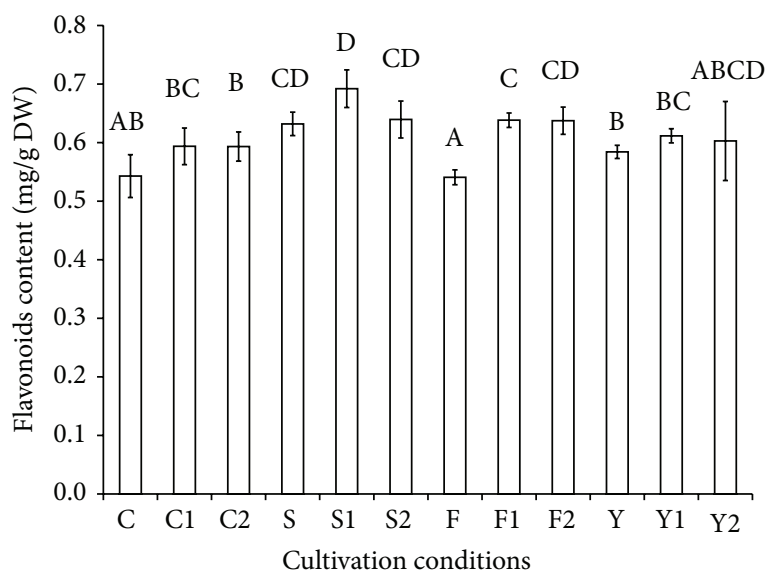

(b)

FIGURE 1: Influence of hydrogen peroxide treatments combined with precursors feeding on the content of total phenolics (a) and flavonoids (b) in quinoa sprouts. Note: means followed by different letters are significantly different at $p=0.05$. Each value represents the mean of three independent experiments $( \pm \mathrm{SD})$. C: control; Cl: treatment with $50 \mathrm{mM} \mathrm{H}_{2} \mathrm{O}_{2}$; C2: treatment with $200 \mathrm{mM} \mathrm{H}_{2} \mathrm{O}_{2}$; S: shikimic acid feeding; S1: treatment with $50 \mathrm{mM} \mathrm{H} \mathrm{H}_{2}$ and shikimic acid feeding; S2: treatment with $200 \mathrm{mM} \mathrm{H}_{2} \mathrm{O}_{2}$ and shikimic acid feeding; F: phenylalanine feeding; F1: treatment with $50 \mathrm{mM} \mathrm{H}_{2} \mathrm{O}_{2}$ and phenylalanine feeding; F2: treatment with $200 \mathrm{mM} \mathrm{H}_{2} \mathrm{O}_{2}$ and phenylalanine feeding; Y: tyrosine feeding; Y1: treatment with $50 \mathrm{mM} \mathrm{H}_{2} \mathrm{O}_{2}$ and tyrosine feeding; Y2: treatment with $200 \mathrm{mM} \mathrm{H}_{2} \mathrm{O}_{2}$ and tyrosine feeding.

$28 \%$, respectively. Surprisingly, the other modifications of sprouting process $\left(\mathrm{H}_{2} \mathrm{O}_{2}\right.$ treatments and precursors feeding) did not cause any increase of the total phenolics content, while a reduction of their content in the sprouts obtained from seeds fed with phenylalanine $(\mathrm{F})$ and those treated with $50 \mathrm{mM} \mathrm{H}_{2} \mathrm{O}_{2}$ (F1) was observed (Figure 1(b)). Compared to the control, the flavonoids content was increased in all the studied sprouts; the best results (a 30\% increase) were found for the sprouts treated with $200 \mathrm{mM}$ obtained from seeds fed with shikimic acid (S2) (Figure 1(b)).

The amounts of total phenolics and flavonoids content are lower than those previously reported by Paśko et al. [8] for 4-day-old dark-sprouted quinoa $\left(20^{\circ} \mathrm{C}\right)$. The cited researchers found that the phenolics content $(2.8 \mathrm{mg} / \mathrm{g} \mathrm{DW})$ in sprouts was strongly affected by illumination conditions. Similar results were obtained in this study after treatment with $50 \mathrm{mM}$ and $200 \mathrm{mM}$ hydrogen peroxide $(\mathrm{C} 1, \mathrm{C} 2)$. So far, an application of $\mathrm{H}_{2} \mathrm{O}_{2}$ effectively increased the vigour, microbiological quality, and phenolics content in lentil [13, 25] and alfalfa sprouts [29]. However, the use in this study modification of sprouting did not affect strongly the total phenolics content; an increase in the flavonoids content was clearly visible. It may be partially explained by the fact that during germination of quinoa seeds only flavonoids are significantly increased, while free phenolic acids content is usually lowered [30].

Similarly to the other studies, an increase of phenolics antioxidants was translated into the antioxidant capacity [11, 31]. The antiradical capacity was significantly increased by all the used modification of sprouting. The highest increase was observed for the sprouts obtained from seeds fed with tyrosine, an increase by about $150 \%$ for Y and Y2 sprouts. Most importantly, in the sprouts obtained from seeds fed with phenolics synthesis precursors, the effect of treatments was also clearly visible (Table 1). Both hydrogen peroxide treatment and precursors feeding caused about a twofold increase of reducing ability. The highest activity was found for the sprouts obtained from seeds fed with phenylalanine and treated with $200 \mathrm{mM} \mathrm{H}_{2} \mathrm{O}_{2}$ (F2; $5.03 \mathrm{mg} \mathrm{TE} / \mathrm{g} \mathrm{DW}$ ) and those obtained from seed fed with tyrosine (Y; $5.26 \mathrm{mg} \mathrm{TE} / \mathrm{g} \mathrm{DW}$ ). There was no strong effect of the used modifications of germination on the chelating power of sprouts; the maximal increase by about $28 \%$ was found for the sprouts obtained from seed fed with tyrosine and treated with $200 \mathrm{mM} \mathrm{H}_{2} \mathrm{O}_{2}$ (Y2).

Due to the fact that reactions with multiple mechanisms are usually involved in the creating of antioxidant capacity it is extremely difficult to measure the "total antioxidant capacity" of complex food system accurately and quantitatively. For a better evaluation of the total antioxidant potential and the effectiveness of the used treatments, the total antioxidant activity index (AI) was proposed. All the studied modifications increased the antioxidant potential of sprouts (at least by $50 \%$ compared to control). The highest AI value (1.95) was calculated for the sprouts obtained from seed fed with tyrosine (Table 1). According to the results, $\mathrm{H}_{2} \mathrm{O}_{2}$ treatments as well as the phenylpropanoid pathway feeding significantly improved antioxidant capacity. Also, compared to the previous studies the antioxidant capacity determined in this study was significantly higher [30]. Most importantly, the effectiveness of the used methodology was very high compared to the other similar studies. An application of stressing factors and precursors feeding for the improving the antioxidant capacity of lentil [19] and buckwheat [15] sprouts caused a maximal increase by about $20 \%$ and $50 \%$, respectively.

In Figures 2 and 3 the activities of enzymes involved in the phenolic synthesis are presented. The activities of L-tyrosine ammonia-lyase (TAL) and L-phenylalanine ammonia-lyase (PAL), two enzymes directly involved in the phenolics synthesis, were diversified by the sprout age as well as the applied modification of sprouting. Generally, differences in the PAL 
TABLE 1: Antioxidant capacity of quinoa sprouts affected by hydrogen peroxide treatments and precursors feeding.

\begin{tabular}{|c|c|c|c|c|}
\hline Cultivation conditions & $\begin{array}{c}\text { Antiradical activity } \\
{[\mathrm{mg} \mathrm{TE} / \mathrm{g} \mathrm{DW}]}\end{array}$ & $\begin{array}{l}\text { Reducing power } \\
{[\mathrm{mg} \mathrm{TE} / \mathrm{g} \text { DW }]}\end{array}$ & $\begin{array}{l}\text { Chelating power } \\
\text { [mg EDTA/g DW] }\end{array}$ & Total antioxidant capacity \\
\hline $\mathrm{C}$ & $0.77 \pm 0.10^{\mathrm{a}}$ & $2.29 \pm 0.10^{\mathrm{a}}$ & $3.38 \pm 0.34^{\mathrm{a}}$ & 1.00 \\
\hline $\mathrm{C} 1$ & $1.08 \pm 0.18^{\mathrm{b}}$ & $4.79 \pm 0.29^{\mathrm{cd}}$ & $4.02 \pm 0.16^{\mathrm{b}}$ & 1.56 \\
\hline $\mathrm{C} 2$ & $1.53 \pm 0.14^{\mathrm{cd}}$ & $4.71 \pm 0.24^{\mathrm{cd}}$ & $3.71 \pm 0.33^{\mathrm{ab}}$ & 1.71 \\
\hline S & $1.42 \pm 0.27^{\mathrm{bcd}}$ & $4.81 \pm 0.45^{\mathrm{cd}}$ & $3.58 \pm 0.20^{\mathrm{ab}}$ & 1.67 \\
\hline S1 & $1.53 \pm 0.16^{\mathrm{cd}}$ & $4.85 \pm 0.47^{\mathrm{cd}}$ & $3.70 \pm 0.23^{\mathrm{ab}}$ & 1.73 \\
\hline S2 & $1.50 \pm 0.16^{\mathrm{cd}}$ & $4.44 \pm 0.11^{\mathrm{c}}$ & $3.89 \pm 0.47^{\mathrm{abc}}$ & 1.68 \\
\hline $\mathrm{F}$ & $1.71 \pm 0.06^{\mathrm{de}}$ & $4.44 \pm 0.37^{\mathrm{bc}}$ & $3.40 \pm 0.30^{\mathrm{a}}$ & 1.72 \\
\hline $\mathrm{F} 1$ & $1.47 \pm 0.21^{\mathrm{cd}}$ & $4.69 \pm 0.51^{\mathrm{cd}}$ & $3.77 \pm 0.52^{\mathrm{abc}}$ & 1.69 \\
\hline $\mathrm{F} 2$ & $1.67 \pm 0.15^{\mathrm{cde}}$ & $5.03 \pm 0.11^{\mathrm{d}}$ & $3.41 \pm 0.73^{\mathrm{ab}}$ & 1.79 \\
\hline $\mathrm{Y}$ & $1.92 \pm 0.08^{\mathrm{e}}$ & $5.26 \pm 0.18^{\mathrm{d}}$ & $3.63 \pm 0.41^{\mathrm{ab}}$ & 1.95 \\
\hline Y1 & $1.58 \pm 0.15^{\mathrm{cde}}$ & $4.70 \pm 0.52^{\mathrm{bcd}}$ & $3.71 \pm 0.44^{\mathrm{ab}}$ & 1.73 \\
\hline Y2 & $1.89 \pm 0.14^{\mathrm{e}}$ & $4.01 \pm 0.12^{\mathrm{b}}$ & $4.34 \pm 0.07^{\mathrm{c}}$ & 1.83 \\
\hline
\end{tabular}

Note: means in columns followed by different letters are significantly different at $p=0.05$. Each value represents the mean of three independent experiments $( \pm \mathrm{SD})$.

C: control; Cl: treatment with $50 \mathrm{mM} \mathrm{H}_{2} \mathrm{O}_{2}$; C2: treatment with $200 \mathrm{mM} \mathrm{H}_{2} \mathrm{O}_{2}$; S: shikimic acid feeding; S1: treatment with $50 \mathrm{mM} \mathrm{H}_{2} \mathrm{O}_{2}$ and shikimic acid feeding; S2: treatment with $200 \mathrm{mM} \mathrm{H}_{2} \mathrm{O}_{2}$ and shikimic acid feeding; F: phenylalanine feeding; F1: treatment with $50 \mathrm{mM} \mathrm{H}_{2} \mathrm{O}_{2}$ and phenylalanine feeding; F2: treatment with $200 \mathrm{mM} \mathrm{H}_{2} \mathrm{O}_{2}$ and phenylalanine feeding; $\mathrm{Y}$ : tyrosine feeding; Y1: treatment with $50 \mathrm{mM} \mathrm{H}_{2} \mathrm{O}_{2}$ and tyrosine feeding; Y2: treatment with $200 \mathrm{mM} \mathrm{H}_{2} \mathrm{O}_{2}$ and tyrosine feeding.

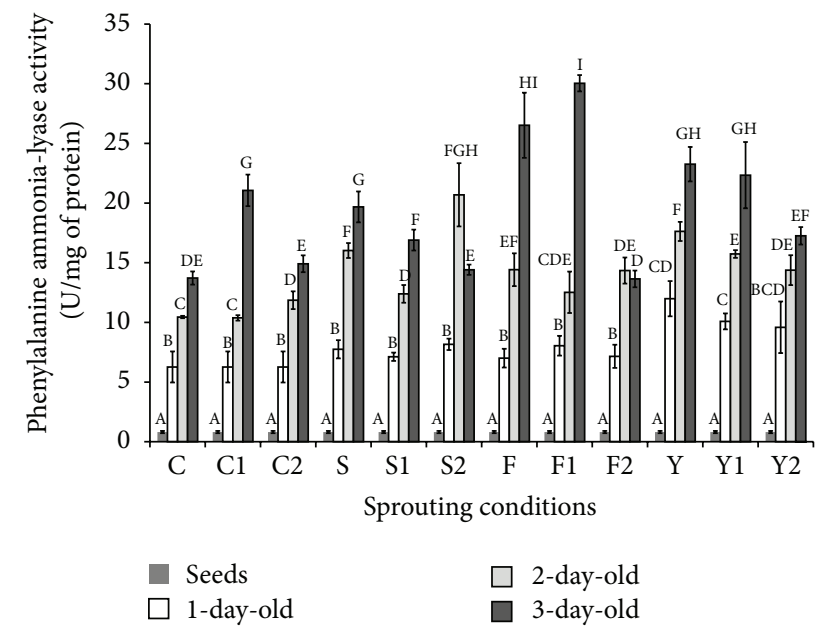

FIGURE 2: Influence of hydrogen peroxide treatments combined with precursors feeding on the phenylalanine ammonia-lyase activity. Note: means in columns followed by different letters are significantly different at $p=0.05$. Each value represents the mean of three independent experiments $( \pm \mathrm{SD})$. C: control; $\mathrm{Cl}$ : treatment with $50 \mathrm{mM} \mathrm{H} \mathrm{O}_{2}$; C2: treatment with $200 \mathrm{mM} \mathrm{H}_{2} \mathrm{O}_{2}$; S: shikimic acid feeding; S1: treatment with $50 \mathrm{mM} \mathrm{H}_{2} \mathrm{O}_{2}$ and shikimic acid feeding; S2: treatment with $200 \mathrm{mM} \mathrm{H}_{2} \mathrm{O}_{2}$ and shikimic acid feeding; F: phenylalanine feeding; $\mathrm{F} 1$ : treatment with $50 \mathrm{mM} \mathrm{H}_{2} \mathrm{O}_{2}$ and phenylalanine feeding; F2: treatment with $200 \mathrm{mM} \mathrm{H}_{2} \mathrm{O}_{2}$ and phenylalanine feeding; Y: tyrosine feeding; Y1: treatment with $50 \mathrm{mM} \mathrm{H}_{2} \mathrm{O}_{2}$ and tyrosine feeding; $\mathrm{Y} 2$ : treatment with $200 \mathrm{mM} \mathrm{H}_{2} \mathrm{O}_{2}$ and tyrosine feeding.

activity were found between the studied sprouts from the 1st day of germination. After 3 days of sprouting the highest activity of PAL was determined in the sprouts obtained

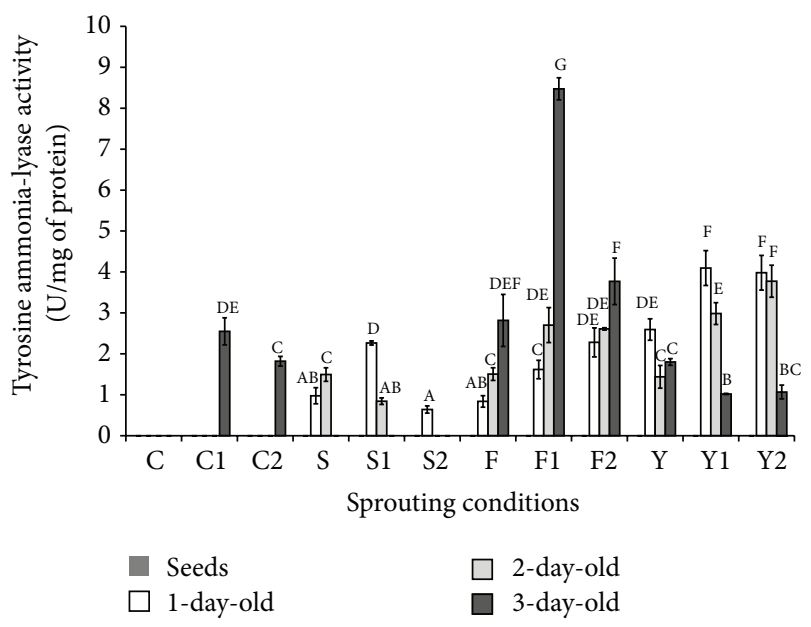

FIGURE 3: Influence of hydrogen peroxide treatments combined with precursors feeding on the tyrosine ammonia-lyase activity. Note: means in columns followed by different letters are significantly different at $p=0.05$. Each value represents the mean of three independent experiments $( \pm S D)$. C: control; $\mathrm{Cl}$ : treatment with $50 \mathrm{mM} \mathrm{H}_{2} \mathrm{O}_{2}$; C2: treatment with $200 \mathrm{mM} \mathrm{H}_{2} \mathrm{O}_{2}$; S: shikimic acid feeding; S1: treatment with $50 \mathrm{mM} \mathrm{H}_{2} \mathrm{O}_{2}$ and shikimic acid feeding; S2: treatment with $200 \mathrm{mM} \mathrm{H}_{2} \mathrm{O}_{2}$ and shikimic acid feeding; $\mathrm{F}$ : phenylalanine feeding; F1: treatment with $50 \mathrm{mM} \mathrm{H}_{2} \mathrm{O}_{2}$ and phenylalanine feeding; F2: treatment with $200 \mathrm{mM} \mathrm{H}_{2} \mathrm{O}_{2}$ and phenylalanine feeding; Y: tyrosine feeding; Y1: treatment with $50 \mathrm{mM} \mathrm{H}_{2} \mathrm{O}_{2}$ and tyrosine feeding; $\mathrm{Y} 2$ : treatment with $200 \mathrm{mM} \mathrm{H}_{2} \mathrm{O}_{2}$ and tyrosine feeding.

from seeds fed with phenylalanine; in both the untreated and the treated with $50 \mathrm{mM} \mathrm{H}_{2} \mathrm{O}_{2}$ ( $\mathrm{F}$ and $\mathrm{F} 1$ ) sprouts about a 2-fold increase was determined. Treatment with $50 \mathrm{mM}$ 
$\mathrm{H}_{2} \mathrm{O}_{2}$ effectively induced PAL activity; however, a positive effect of phenylalanine feeding was also observed (Figure 2). There was no TAL activity in the dormant seeds and sprouts germinated at control conditions. Most importantly, $\mathrm{H}_{2} \mathrm{O}_{2}$ treatment induced TAL activity, which was especially visible in the case of 3-day-old control sprouts. The highest TAL activity was determined for the 3-day-old sprouts treated with $200 \mathrm{mM} \mathrm{H}_{2} \mathrm{O}_{2}$ obtained from seeds soaked in $0.1 \mathrm{mM}$ phenylalanine. A significant increase was also determined for the 1- and 2-day-old induced sprouts obtained from seeds fed with tyrosine (Figure 3). Similar to this study an increase of PAL and TAL activity after UV-B treatments of lentil seeds was observed by Świeca et al. [19]. An increase of phenolics level in the broccoli sprouts treated with mannitol and sucrose observed by Guo et al. [32] was also correlated with the increased activity of PAL. From the nutritional point of view, increasing concentration of lowmolecular-weight antioxidants resulted in higher antioxidant capacity that is one of the most important effects observed in sprouts after induction of their metabolism with stress and/or elicitors. Although an elevation of phenolics in the studied quinoa sprouts was much lower than that of antioxidant potential it may be suggested that in the complex food matrix bioactive components interact with themselves; a synergistic effect may take place similar to the other studies [33]. It may be also suggested that low-molecular compounds, for example, vitamin $\mathrm{E}$ or peptides, may be responsible for the increased antioxidant potential; however, the positive effect of precursor feeding suggests that phenolics play a key role. This statement seems to be also supported by the fact that chelating power [34], usually created by bioactive peptides in the protein-rich product, was not significantly changed in the studied sprouts.

\section{Conclusion}

It has been proven that antioxidant capacity of quinoa sprouts may be successfully increased by treatments with $\mathrm{H}_{2} \mathrm{O}_{2}$ combined with the phenylpropanoids precursors feeding. It is all the more important in the light of the excellent nutritional quality of quinoa sprouts and relatively low antioxidant capacity (compared to the other commonly consumed sprouts). Most importantly, according to the pattern of changes in the activity of two main enzymes involved in the synthesis of phenolics antioxidants it may be stated that they are synthesized de novo. The best results were found after tyrosine feeding, about a 2fold increase of total antioxidant capacity (compared to untreated sprouts). The obtained sprouts were characterized by an increased content of flavonoids, improved reducing power, and antiradical activity. As the antioxidant activity of food is linked with its prohealth properties it may be suggested that sprouts obtained in this study possess an additional value and may be included to the functional food.

\section{Competing Interests}

The author declares that there are no competing interests regarding the publication of this paper.

\section{References}

[1] I. Siró, E. Kápolna, B. Kápolna, and A. Lugasi, "Functional food. Product development, marketing and consumer acceptance-a review," Appetite, vol. 51, no. 3, pp. 456-467, 2008.

[2] M. Miranda, A. Vega-Gálvez, J. López et al., "Impact of airdrying temperature on nutritional properties, total phenolic content and antioxidant capacity of quinoa seeds (Chenopodium quinoa Willd.)," Industrial Crops and Products, vol. 32, no. 3, pp. 258-263, 2010.

[3] A. Bhargava, S. Shukla, and D. Ohri, "Chenopodium quinoaan Indian perspective," Industrial Crops and Products, vol. 23, no. 1, pp. 73-87, 2006.

[4] U. Gawlik-Dziki, M. Świeca, M. Sułkowski, D. Dziki, B. Baraniak, and J. Czyz, "Antioxidant and anticancer activities of Chenopodium quinoa leaves extracts-in vitro study," Food and Chemical Toxicology, vol. 57, pp. 154-160, 2013.

[5] Y. Tang, X. Li, P. X. Chen et al., "Characterisation of fatty acid, carotenoid, tocopherol/tocotrienol compositions and antioxidant activities in seeds of three Chenopodium quinoa Willd. genotypes," Food Chemistry, vol. 174, pp. 502-508, 2015.

[6] U. Gawlik-Dziki, D. Dziki, M. Świeca, Ł. Sęczyk, R. Różyło, and U. Szymanowska, "Bread enriched with Chenopodium quinoa leaves powder-the procedures for assessing the fortification efficiency," LWT-Food Science and Technology, vol. 62, no. 2, pp. 1226-1234, 2015.

[7] R. Repo-Carrasco-Valencia, J. K. Hellström, J.-M. Pihlava, and P. H. Mattila, "Flavonoids and other phenolic compounds in Andean indigenous grains: quinoa (Chenopodium quinoa), kañiwa (Chenopodium pallidicaule) and kiwicha (Amaranthus caudatus)," Food Chemistry, vol. 120, no. 1, pp. 128-133, 2010.

[8] P. Paśko, H. Bartoń, P. Zagrodzki, S. Gorinstein, M. Fołta, and Z. Zachwieja, "Anthocyanins, total polyphenols and antioxidant activity in amaranth and quinoa seeds and sprouts during their growth," Food Chemistry, vol. 115, no. 3, pp. 994-998, 2009.

[9] B. A. Cevallos-Casals and L. Cisneros-Zevallos, "Impact of germination on phenolic content and antioxidant activity of 13 edible seed species," Food Chemistry, vol. 119, no. 4, pp. 14851490, 2010.

[10] C. Vidal-Valverde, J. Frias, I. Sierra, I. Blazquez, F. Lambein, and Y.-H. Kuo, "New functional legume foods by germination: effect on the nutritive value of beans, lentils and peas," European Food Research and Technology, vol. 215, no. 6, pp. 472-477, 2002.

[11] M. Świeca, U. Gawlik-Dziki, D. Kowalczyk, and U. Złotek, "Impact of germination time and type of illumination on the antioxidant compounds and antioxidant capacity of Lens culinaris sprouts," Scientia Horticulturae, vol. 140, pp. 87-95, 2012.

[12] J. Zhao, L. C. Davis, and R. Verpoorte, "Elicitor signal transduction leading to production of plant secondary metabolites," Biotechnology Advances, vol. 23, no. 4, pp. 283-333, 2005.

[13] M. Świeca, "Production of ready-to-eat lentil sprouts with improved antioxidant capacity: optimization of elicitation conditions with hydrogen peroxide," Food Chemistry, vol. 180, pp. 219-226, 2015. 
[14] D. Dziki, U. Gawlik-Dziki, M. Kordowska-Wiater, and M. Domań-Pytka, "Influence of elicitation and germination conditions on biological activity of wheat sprouts," Journal of Chemistry, vol. 2015, Article ID 649709, 8 pages, 2015.

[15] M. Świeca, "Potentially bioaccessible phenolics, antioxidant activity and nutritional quality of young buckwheat sprouts affected by elicitation and elicitation supported by phenylpropanoid pathway precursor feeding," Food Chemistry, vol. 192, pp. 625-632, 2016.

[16] R. Yang, L. Guo, X. Jin, C. Shen, Y. Zhou, and Z. Gu, "Enhancement of glucosinolate and sulforaphane formation of broccoli sprouts by zinc sulphate via its stress effect," Journal of Functional Foods, vol. 13, pp. 345-349, 2015.

[17] M. Li, X. Chen, P. Wang, and F. Ma, "Ascorbic acid accumulation and expression of genes involved in its biosynthesis and recycling in developing apple fruit," Journal of the American Society for Horticultural Science, vol. 136, no. 4, pp. 231-238, 2011.

[18] S. Pérez-Balibrea, D. A. Moreno, and C. García-Viguera, "Improving the phytochemical composition of broccoli sprouts by elicitation," Food Chemistry, vol. 129, no. 1, pp. 35-44, 2011.

[19] M. Świeca, Ł. Sęczyk, and U. Gawlik-Dziki, "Elicitation and precursor feeding as tools for the improvement of the phenolic content and antioxidant activity of lentil sprouts," Food Chemistry, vol. 161, pp. 288-295, 2014.

[20] V. L. Singleton, R. Orthofer, and R. M. Lamuela-Raventós, Oxidants and Antioxidants Part A, vol. 299, Elsevier, Amsterdam, The Netherlands, 1999.

[21] J. Lamaison and A. Carnet, “Teneurs en principaux flavonoids des fleurs de Crataegeus monogyna Jacq et de Crataegeus laevigata (Poiret D. C) en fonction de la vegetation," Pharmaceutica Acta Helvetiae, vol. 65, pp. 315-320, 1990.

[22] R. Re, N. Pellegrini, A. Proteggente, A. Pannala, M. Yang, and C. Rice-Evans, "Antioxidant activity applying an improved ABTS radical cation decolorization assay," Free Radical Biology and Medicine, vol. 26, no. 9-10, pp. 1231-1237, 1999.

[23] M. Oyaizu, "Studies on products of browning reactionantioxidative activities of products of browning reaction prepared from glucosamine," The Japanese Journal of Nutrition and Dietetics, vol. 44, no. 6, pp. 307-315, 1986.

[24] E. A. Decker and B. Welch, "Role of ferritin as a lipid oxidation catalyst in muscle food," Journal of Agricultural and Food Chemistry, vol. 38, no. 3, pp. 674-677, 1990.

[25] M. Świeca and B. Baraniak, "Influence of elicitation with $\mathrm{H}_{2} \mathrm{O}_{2}$ on phenolics content, antioxidant potential and nutritional quality of Lens culinaris sprouts," Journal of the Science of Food and Agriculture, vol. 94, no. 3, pp. 489-496, 2014.

[26] J. S. Assis, R. Maldonado, T. Muñoz, M. I. Escribano, and C. Merodio, "Effect of high carbon dioxide concentration on PAL activity and phenolic contents in ripening cherimoya fruit," Postharvest Biology and Technology, vol. 23, no. 1, pp. 33-39, 2001.

[27] M. M. Bradford, "A rapid and sensitive method for the quantitation of microgram quantities of protein utilizing the principle of protein-dye binding," Analytical Biochemistry, vol. 72, no. 1-2, pp. 248-254, 1976.

[28] R. Yawadio Nsimba, H. Kikuzaki, and Y. Konishi, "Antioxidant activity of various extracts and fractions of Chenopodium quinoa and Amaranthus spp. seeds," Food Chemistry, vol. 106, no. 2, pp. 760-766, 2008.

[29] E.-J. Hong and D.-H. Kang, "Effect of sequential dry heat and hydrogen peroxide treatment on inactivation of Salmonella
Typhimurium on alfalfa seeds and seeds germination," Food Microbiology, vol. 53, pp. 9-14, 2016.

[30] L. Alvarez-Jubete, H. Wijngaard, E. K. Arendt, and E. Gallagher, "Polyphenol composition and in vitro antioxidant activity of amaranth, quinoa buckwheat and wheat as affected by sprouting and baking," Food Chemistry, vol. 119, no. 2, pp. 770-778, 2010.

[31] U. Szymanowska, U. Złotek, M. Karaś, and B. Baraniak, "Antiinflammatory and antioxidative activity of anthocyanins from purple basil leaves induced by selected abiotic elicitors," Food Chemistry, vol. 172, pp. 71-77, 2015.

[32] R. Guo, G. Yuan, and Q. Wang, "Effect of sucrose and mannitol on the accumulation of health-promoting compounds and the activity of metabolic enzymes in broccoli sprouts," Scientia Horticulturae, vol. 128, no. 3, pp. 159-165, 2011.

[33] A. Durak, U. Gawlik-Dziki, and I. Kowlska, "Coffee with ginger-interactions of biologically active phytochemicals in the model system," Food Chemistry, vol. 166, pp. 261-269, 2015.

[34] L. Guo, P. A. Harnedy, B. Li et al., "Food protein-derived chelating peptides: biofunctional ingredients for dietary mineral bioavailability enhancement," Trends in Food Science and Technology, vol. 37, no. 2, pp. 92-105, 2014. 

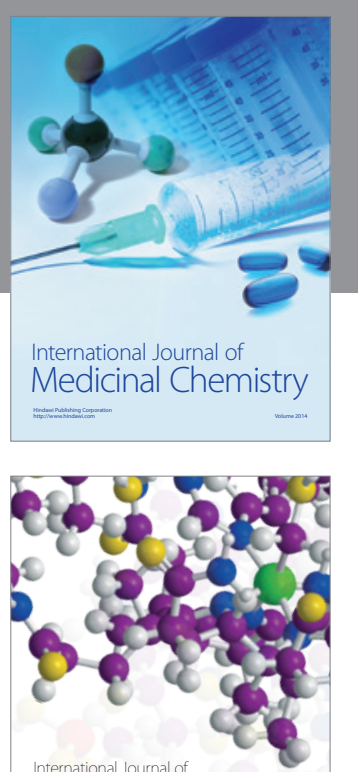

Carbohydrate Chemistry

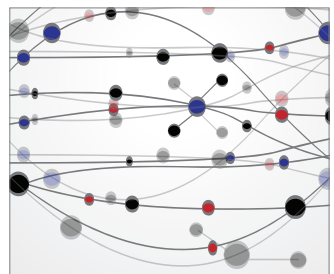

The Scientific World Journal
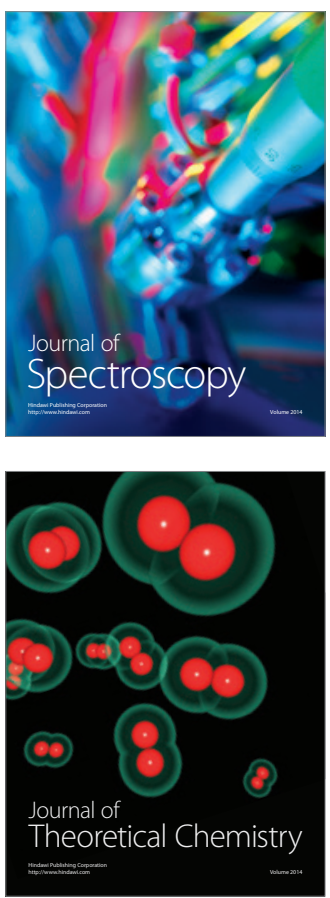
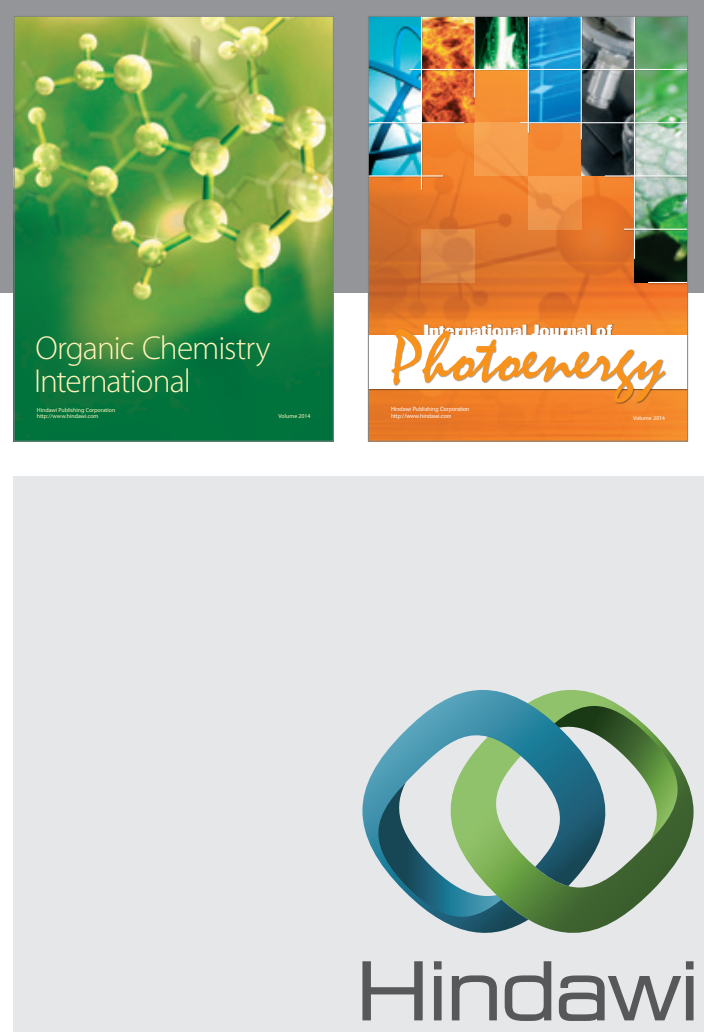

Submit your manuscripts at

http://www.hindawi.com

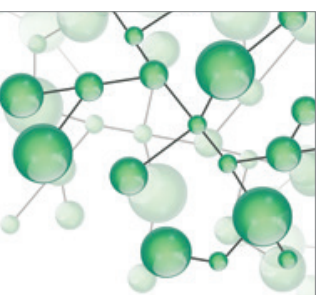

International Journal of

Inorganic Chemistry

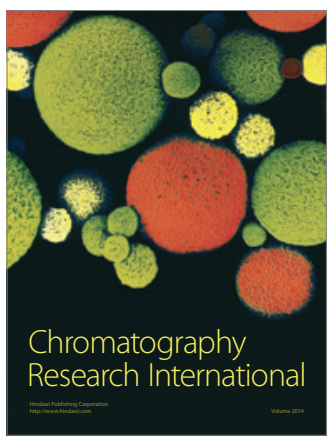

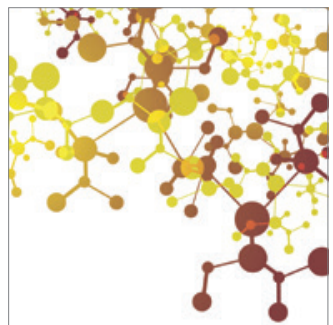

Applied Chemistry
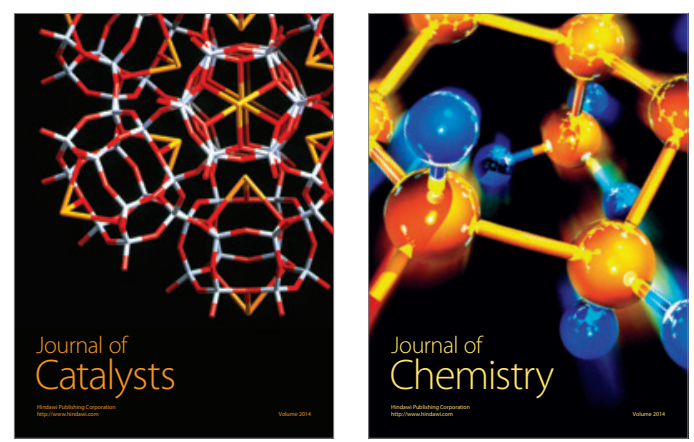
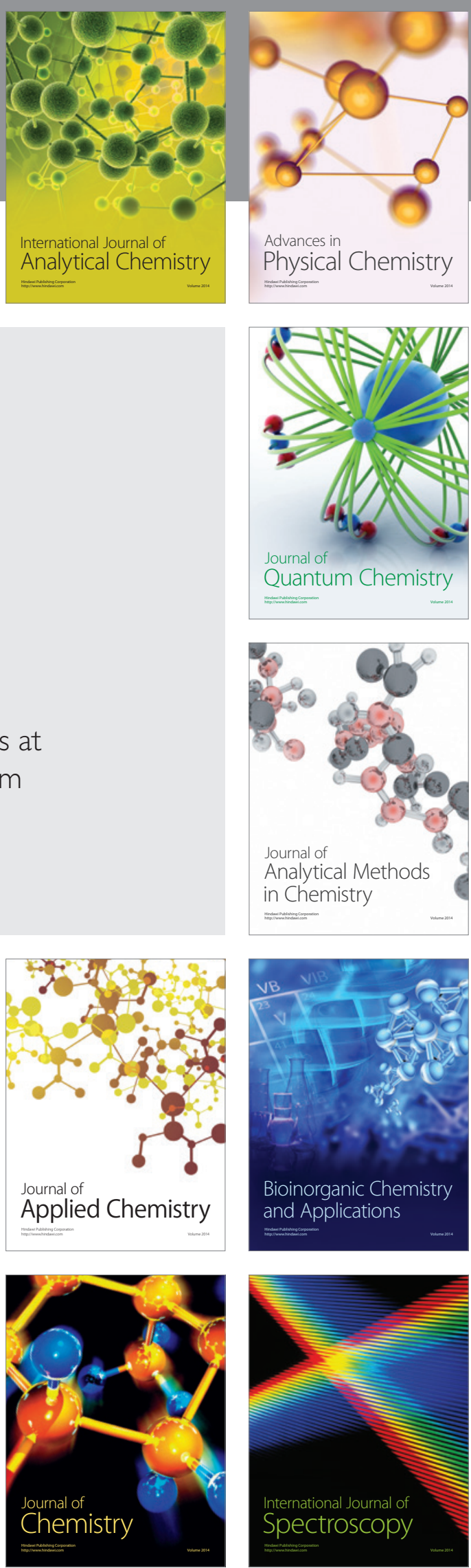